\title{
Cleavage of polypeptide chain initiation factor elF4GI during apoptosis in lymphoma cells: characterisation of an internal fragment generated by caspase-3-mediated cleavage
}

\author{
M Bushell ${ }^{1}$, D Poncet ${ }^{2}$, WE Marissen ${ }^{3}$, H Flotow $^{4}$, RE Lloyd ${ }^{3}$, \\ MJ Clemens ${ }^{\star, 1}$ and SJ Morley \\ ${ }^{1}$ Department of Biochemistry and Immunology, Cellular and Molecular \\ Sciences Group, St George's Hospital Medical School, Cranmer Terrace, \\ London SW17 ORE, UK \\ ${ }^{2}$ Laboratoire de Virologie et Immunologie Moleculaires, INRA, Domaine de \\ Vilvert, 78352 Jouy-en-Josas, Cedex, France \\ ${ }^{3}$ Department of Molecular Virology, Baylor College of Medicine, One Baylor \\ Plaza, Houston, TX 77030, USA \\ ${ }^{4}$ Roche Discovery Welwyn, Broadwater Road, Welwyn Garden City, \\ Hertfordshire AL7 3AY, UK \\ ${ }^{5}$ Biochemistry Group, School of Biological Sciences, University of Sussex, \\ Brighton BN1 9QG, UK \\ * Corresponding author: MJ Clemens, Department of Biochemistry and \\ Immunology, Cellular and Molecular Sciences Group, St George's Hospital \\ Medical School, Cranmer Terrace, London SW17 ORE, UK, \\ Tel: +44 208725 5770; Fax: +44 208725 2992; \\ E-mail: M.Clemens@sghms.ac.uk
}

Received 22.12.99; revised 22.3.00; accepted 28.3.00

Edited by RA Knight

\begin{abstract}
Polypeptide chain initiation factor elF4GI undergoes caspasemediated degradation during apoptosis to give characteristic fragments. The most prominent of these has an estimated mass of approximately $76 \mathrm{kDa}$ (Middle-Fragment of Apoptotic cleavage of elF4G; M-FAG). Subcellular fractionation of the BJAB lymphoma cell line after induction of apoptosis indicates that M-FAG occurs in both ribosome-bound and soluble forms. Affinity chromatography on $m^{7} G T P$-Sepharose shows that M-FAG retains the ability of elF4GI to associate with both the mRNA cap-binding protein elF4E and initiation factor elF4A and that the ribosome-bound form of M-FAG is also present as a complex with elF4E and elF4A. These data suggest that the binding sites for elF4E, elF4A and elF3 on elF4GI are retained in the caspase-generated fragment. M-FAG is also a substrate for cleavage by the Foot-and-MouthDisease Virus-encoded L protease. These properties, together with the pattern of recognition by a panel of antibodies, define the origin of the apoptotic cleavage fragment. $\mathrm{N}$-terminal sequencing of the products of caspase-3-mediated elF4GI cleavage has identified the major cleavage sites. The pattern of elF4GI degradation and the possible roles of the individual cleavage products in cells undergoing apoptosis are discussed. Cell Death and Differentiation (2000) 7, 628-636.
\end{abstract}

Keywords: apoptosis; BJAB cells; caspases; elF4G; initiation factors; protein sequencing
Abbreviations: Ct, C-terminal fragment of elF4G; elFs, eukaryotic initiation factors; FAG, fragment of the apoptotic cleavage of elF4G; FMDV, foot-and-mouth-disease virus; $m^{7} G T P$, 7-methylguanosine triphosphate; PABP, poly(A) binding protein; PARP, poly(ADP-ribose) polymerase; z-VAD.FMK, Z-Val-Ala-Asp.fluoromethylketone

\section{Introduction}

In eukaryotic cells the polypeptide chain initiation factor elF4G plays an essential role in the mechanism of translation by acting as a molecular bridge between other components of the ribosomal initiation complex (reviewed in references ${ }^{1-3}$ ). Two forms of elF4G, which are products of different genes, have been identified. ${ }^{4}$ elF4GI is a single polypeptide chain of at least $154 \mathrm{kDa} ;{ }^{5}$ recently extensions to the original $\mathrm{N}$ terminal sequence of this protein have been described, ${ }^{6-8}$ and it is possible that the true $\mathrm{N}$-terminus has not yet been identified. In vivo elF4G exists partly in the form of a complex with the mRNA cap-binding protein elF4E and the ATPdependent RNA helicase elF4A, constituting the initiation factor elF4F. ${ }^{9}$ Within the sequence of elF4GI ${ }^{9}$ there are domains that interact with elF4E, ${ }^{10}$ elF4A, ${ }^{10,11}$, elF3, ${ }^{11}$ the poly $(A)$ binding protein $(P A B P)^{7,12-14}$ and the elF4E kinase Mnk1. ${ }^{15}$ Interaction of PABP with elF4GI has been suggested to facilitate the functional association of the $3^{\prime}$ end of an mRNA with the $5^{\prime}$ end. ${ }^{14}$ The association of elF4G with elF4E markedly enhances the binding of the latter to the mRNA $\operatorname{cap}^{16}$ and is necessary to permit cap-dependent translation. It is also likely that the phosphorylation of elF4E, which has been correlated with enhanced translational activity in cells treated with mitogens and growth factors, ${ }^{17-20}$ is facilitated by the binding of the elF4E kinase Mnk1 to the C-terminal part of elF4GI. ${ }^{15}$ Over-expression of either elF4G or elF4E has been shown to transform cells to a tumorigenic phenotype, ${ }^{21,22}$ and abnormally high levels of both factors have been observed in several types of human tumours. ${ }^{23-25}$

There is a well-characterised loss of integrity of both elF4GI (reviewed in reference ${ }^{2}$ ) and elF4GII ${ }^{4,26}$ in mammalian cells after infection with picornaviruses such as Polio or Foot-and-Mouth-Disease viruses (FMDV). This is a result of cleavage at specific internal sites by the virally-encoded $2 A$ and $L$ proteases, respectively. Since these cleavages occur in a region between the elF4E and elF3 binding sites ${ }^{27}$ they destroy the bridging function of elF4G and thus lead to the inhibition of cap-dependent initiation. ${ }^{28-32}$ The remaining C-terminal fragment of elF4G can nevertheless still support initiation that is capindependent $^{28}$ or that involves ribosome binding to internal sites on mRNAs. ${ }^{33}$ 
We have shown that elF4GI is rapidly cleaved during the process of apoptosis (cell death) that can be induced by a variety of treatments in several cell lines. ${ }^{34-36}$ This effect is selective since several other initiation factors, including elF4E and elF4A, are relatively stable under these conditions. In cells undergoing apoptosis proteolysis of elF4GI to produce characteristic cleavage fragments is mediated by one or more caspases, ${ }^{34}$ and caspase-3 activity is both necessary and sufficient for this process. ${ }^{36,37}$ Protein synthesis is strongly inhibited in cells undergoing apoptosis and in some situations this inhibition, as well as the cleavage of elF4GI, can be prevented by incubation with the cell-permeable caspase inhibitor, zVAD.FMK. ${ }^{34-36}$ It is possible that the down-regulation of translation in apoptotic cells is due to the specific and complete cleavage of elF4G. However the remaining protein synthetic activity (which amounts to some $35 \%$ of the control rate $^{35}$ ) may be maintained by the continued presence of one or more cleavage fragments that retain the ability to interact with other key initiation factors. If this is the case it is also likely that the properties of the cleavage fragments that appear during apoptosis are distinct from those of the fragments of elF4G produced in cells during picornavirus infection, which do not support any capdependent initiation. ${ }^{28-32}$

To begin to test these hypotheses we have identified the sites of the caspase-mediated cleavages of elF4GI that occur rapidly during cellular apoptosis and have characterised the properties of the major cleavage products $(\mathrm{N}$ FAG, M-FAG and C-FAG) that persist in cells for several hours after fragmentation of the full-length factor. Our results indicate that the cleavages that occur and the nature of the fragments that result, are quite distinct from those seen in picornavirus-infected cells. The properties of the M-FAG fragment observed in apoptotic cells are compatible with the possibility that this protein can still support cap-dependent initiation but with a substantially impaired efficiency.

\section{Results}

\section{Characterisation of the cleavage fragments of elF4G in apoptotic cells}

Treatment of the EBV-negative Burkitt's lymphoma BJAB cell line with agents such as anti-Fas (CD95) antibody, etoposide and cycloheximide induces apoptosis. In this system cycloheximide is the most potent and rapidly acting of the inducers examined, as revealed by FACS analysis of the extent of accumulation of cells with a less than G0/G1 DNA content (Figure 1A). We have reported previously that all of these treatments also result in the complete cleavage of elF4GI into a series of characteristic fragments. ${ }^{34}$ Figure $1 \mathrm{~B}$ illustrates the time-course of elF4GI cleavage in response to induction of apoptosis with cycloheximide, as visualised with a number of domain and sequence-specific antisera (W, RL, E; see Materials and Methods and Figure 3). In agreement with our previous data, ${ }^{34,35}$ antiserum generated against a large $C$ terminal fragment of elF4G (W) showed that cycloheximide induced the cleavage of total cytoplasmic elF4GI to yield the novel ca. 76 kDa fragment (M-FAG; Figure 1B, lanes 4-6). Cleavage of elF4GI correlated temporally with that of the classical apoptotic substrate, poly(ADP-ribose) polymerase (PARP; lanes 4-6). M-FAG is actually a doublet, the levels of both components of which remain constant within cells for several hours after induction of apoptosis. In addition, with this antiserum we have observed the transient generation of smaller amounts of elF4GI fragments of approximately $150 \mathrm{kDa}$ ( 150 , see Figure 2A) and $120 \mathrm{kDa}$ (p120, faintly visible in Figure $1 \mathrm{~B}$ and $2 \mathrm{~A}$ ), which appear within $2 \mathrm{~h}$ of cycloheximide treatment. The $\mathrm{N}$-terminal sequence-specific antiserum $(R L)$ visualised a group of previously described cleavage products (elF4GcpN), ${ }^{36}$ which we designate $\mathrm{N}$ $F A G$, and the C-terminal sequence-specific antiserum (E) recognised a novel fragment of approximately $50 \mathrm{kDa}$ (CFAG) (Figure 1B). The same pattern of cleavages was observed after treatment with other inducers of apoptosis (serum deprivation, anti-Fas antiserum and etoposide - data not shown). Similar results were also seen using antisera specific to elF4GII, although in this case a different pattern of cleavages occurred. ${ }^{38}$

We also assessed the levels of several other initiation factors in the BJAB cells under the same conditions. Figure $1 \mathrm{~B}$ shows that, in agreement with our previous results, ${ }^{34}$ the levels and integrity of poly(A)-binding protein (PABP), elF4A and total elF4E were unaffected in apoptotic cells. However, use of antiserum which was specific for the phosphorylated form of elF4E ${ }^{39}$ indicated that the phosphorylation status of elF4E decreased at later times following the induction of apoptosis (Figure 1B, lanes 4-6).

\section{Association of the cleavage fragments of elF4G with eIF4E and ribosomes}

Initiation factor elF4E and associated proteins were isolated by $\mathrm{m}^{7}$ GTP-Sepharose chromatography (Figure 1C). Immunoblotting of the $\mathrm{m}^{7} \mathrm{GTP}$-Sepharose-purified proteins revealed that M-FAG (lanes 4-6), p120 (lanes 4, 5) and elF4A (lanes 4-6) remained associated with elF4E in cells in which essentially all of the elF4GI had been cleaved. However, when protein recovered by $\mathrm{m}^{7} \mathrm{GTP}$-Sepharose was visualised with antisera specific for N-FAG or C-FAG, these characteristic fragments were absent, indicating that neither of these products remains associated with elF4E (Figure 1C, lanes 4$6)$. Consistent with this and the location of the site of interaction of PABP with elF4GI in the N-terminal domain of the latter protein,, 6 the level of PABP recovered using $\mathrm{m}^{7}$ GTP-Sepharose chromatography was decreased following the induction of apoptosis (data not shown). These data suggest that M-FAG retains binding sites for elF4E and elF4A but has lost the $\mathrm{N}$-terminal and $\mathrm{C}$-terminal regions of elF4GI.

A significant proportion of elF4GI is bound to ribosomes in mammalian cells. ${ }^{40}$ This is believed to be a consequence of the association of elF4GI with elF3 which is attached to native ribosomal subunits. ${ }^{11}$ We have investigated whether the cleavage fragments of elF4GI retain the ability to bind to ribosomes in apoptotic cells. Figure $2 \mathrm{~A}$ shows that although some M-FAG was found in the post-ribosomal supernatant of apoptotic cells (lane 4), a substantial proportion of this fragment was retained by the ribosomes 

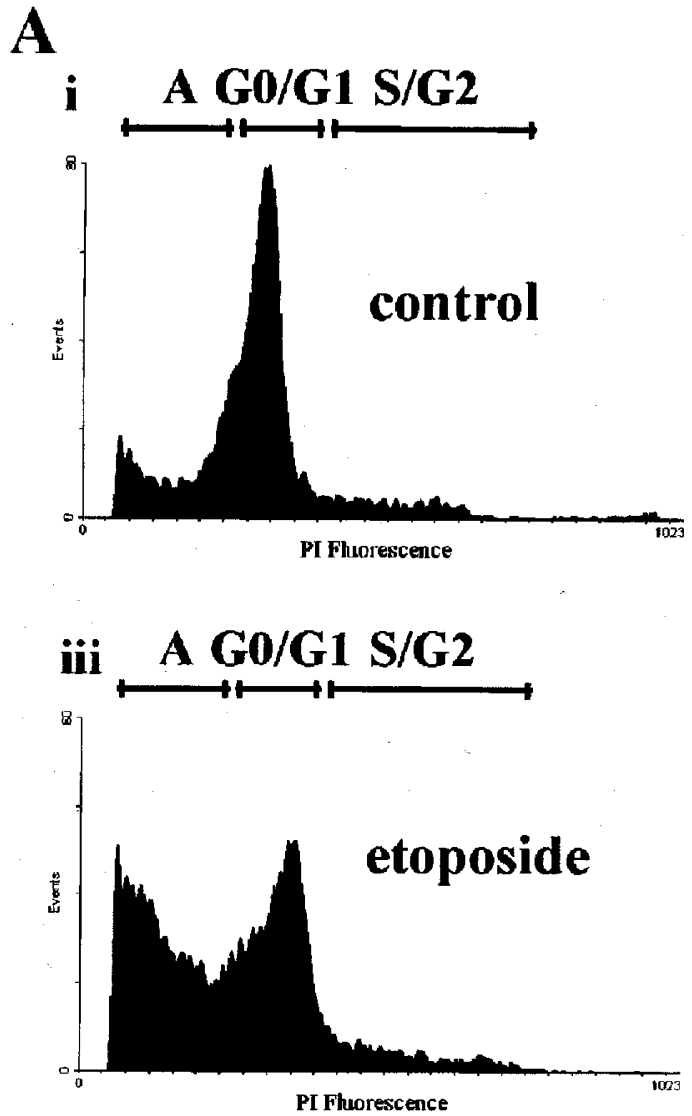

B

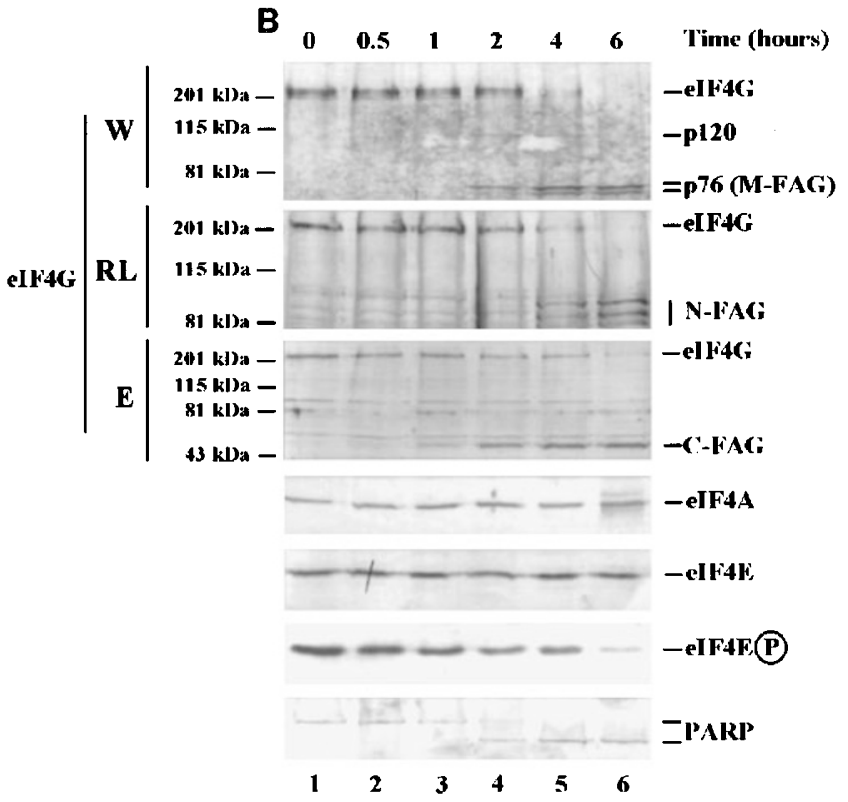

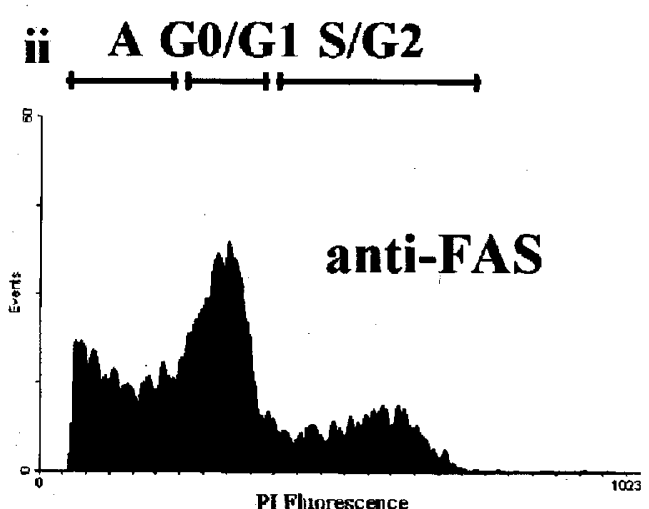

PI Fluorescence

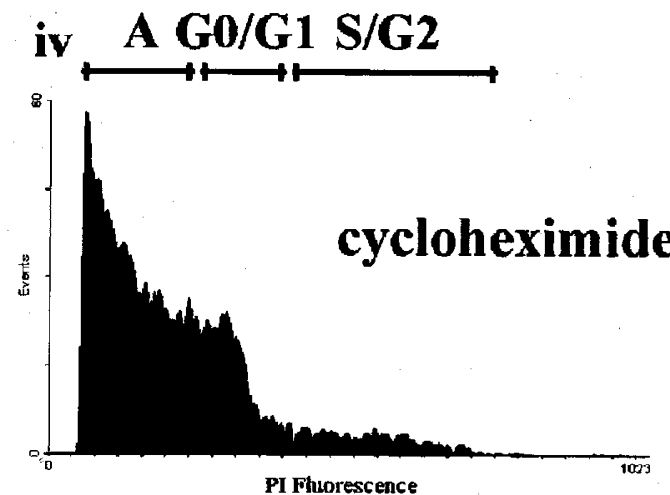

C
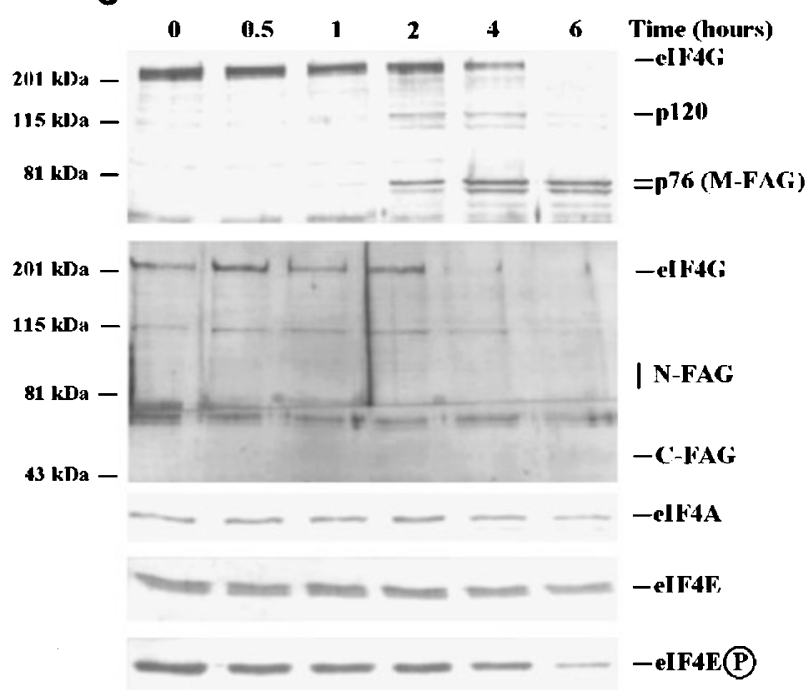

$\begin{array}{llllll}1 & 2 & 3 & 4 & 5 & 6\end{array}$

Figure 1 Induction of apoptosis in BJAB cells: Time-course of elF4GI cleavage and analysis of the ability of the cleavage fragments to interact with elF4E. (A) Determination of the extent of apoptosis by FACS analysis of DNA content. Cells were incubated without or with anti-Fas antibody ( $50 \mathrm{ng} / \mathrm{ml})$ or etoposide ( $100 \mu \mathrm{g} /$ $\mathrm{ml}$ ) for $24 \mathrm{~h}$ or with cycloheximide $(100 \mu \mathrm{g} / \mathrm{ml})$ for $12 \mathrm{~h}$. They were then stained with propidium iodide and their DNA content determined by FACS analysis as described previously. ${ }^{34}$ Regions of each profile corresponding to cells in the G0/G1 or S/G2 phases of the cell cycle and to apoptotic cells with a sub-G1 DNA content (labelled 'A') are indicated. (B) Exponentially growing cells were treated with cycloheximide for the times shown and cytoplasmic extracts prepared as described in the Materials and Methods. Equal quantities of protein from each extract were subjected to SDS gel electrophoresis, followed by immunoblotting for elF4GI (with antiserum W, RL, or E), elF4A, elF4E, the phosphorylated form of elF4E and PARP, as indicated. Molecular mass markers and the locations of the group of N-terminal fragments (N-FAG), the middle fragment (M-FAG), and the C-terminal (C-FAG) fragment of elF4GI (see Figure 3A), together with a faintly stained transient intermediate (p120), are indicated. These data are from a single experiment but are representative of those obtained on five separate occasions. 
(lane 6). Similarly, both the p150 and p120 fragments of elF4GI were recovered with the ribosomal fraction (lane 6) whether apoptosis was induced with cycloheximide (Figure 2A) or etoposide (data not shown). Thus it is likely that these fragments also retain the domain that is required for the association of elF4GI with elF3 (and hence the ribosome) in vivo. To address whether these ribosomalbound fragments of elF4Gl further possess the ability to interact with elF4E, we have isolated elF4E and associated proteins from these fractions by $m^{7} G T P$-Sepharose chromatography. Analysis by immunoblotting of total (Figure 2B, lanes 1, 2), ribosome-free (lanes 3, 4) and ribosome-bound material (lanes 5,6 ) showed the presence of some p150 (faint band in lane 6), p120 (lanes 2, 4, 6) and M-FAG fragments of elF4G (lanes 2, 4, 6) associated with elF4E in extracts from apoptotic cells.

\section{Identification of the caspase-3 cleavage sites in elF4G and comparison with picornavirus protease-mediated cleavage}

We have compared the caspase-3-generated elF4GI cleavage products with the fragments produced by the sitespecific $L$ protease from FMDV (Figure $2 C$ ). Incubation of a reticulocyte lysate with $L$ protease generated the characteristic cleavage fragment, $\mathrm{Ct}$, which lacks the elF4E binding site $^{28,41}$ and is distinct from M-FAG (compare lane 3 with lane 1). Exposure to caspase-3 alone generated p120 and M-FAG (lane 2 versus lane 1) while incubation of reticulocyte lysate with $\mathrm{L}$ protease followed by caspase-3 led to the further cleavage of $\mathrm{Ct}$ to give an even smaller product (lane 4 versus lane 3). Thus $\mathrm{Ct}$ remains sensitive to caspase attack. Incubation of extracts from apoptotic cells with $L$ protease in vitro showed that the viral enzyme degraded not only fulllength elF4GI to produce the $\mathrm{Ct}$ fragment, but further processed the p120 and M-FAG fragments, resulting in loss of binding to elF4E (data not shown). In addition, immunoblots using antiserum $\mathrm{RL}$ demonstrated that the $\mathrm{N}$-terminal fragment of elF4G released by poliovirus $2 \mathrm{~A}$ protease cleavage between residues 642 and 643 (using the numbering system of Imataka et al. ${ }^{7}$ ) could also serve as a substrate for caspase-3 (data not shown). Together these data indicate that $\mathrm{p} 120$ and M-FAG can bind to both elF4E and ribosomes and that the specific sites of $L$ and $2 A$ protease cleavage are distinct from those utilized by caspase-3.

Previously we have shown that caspase- 3 is both necessary and sufficient for the cleavage of elF4GI. ${ }^{37}$ To determine the sites of cleavage of elF4GI by this enzyme we have incubated purified, baculovirus-expressed FLAGelF4GI with caspase-3 in vitro and analyzed the resulting fragments by immunoblotting with sequence-specific antisera followed by mass spectrometry and protein sequencing. Figure $3 \mathrm{~A}$ shows a domain map of elF4Gl with the binding sites for elF4E, elF3, elF4A and PABP, indicating the regions to which antisera were raised. These antisera were directed against large regions of the C-terminus (W) or the N-terminus (RL) of elF4GI, as described in Materials and Methods, and against three peptide epitopes $(\mathrm{B}, \mathrm{H}$ and

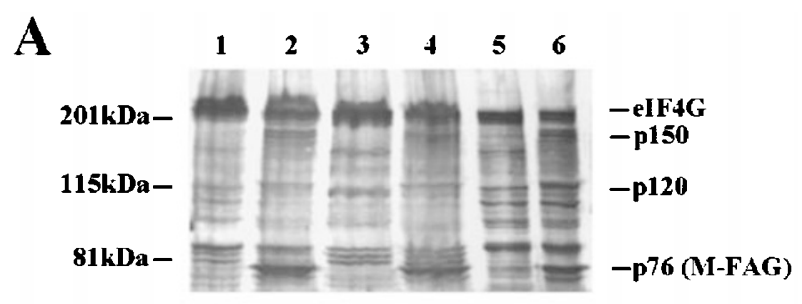

B
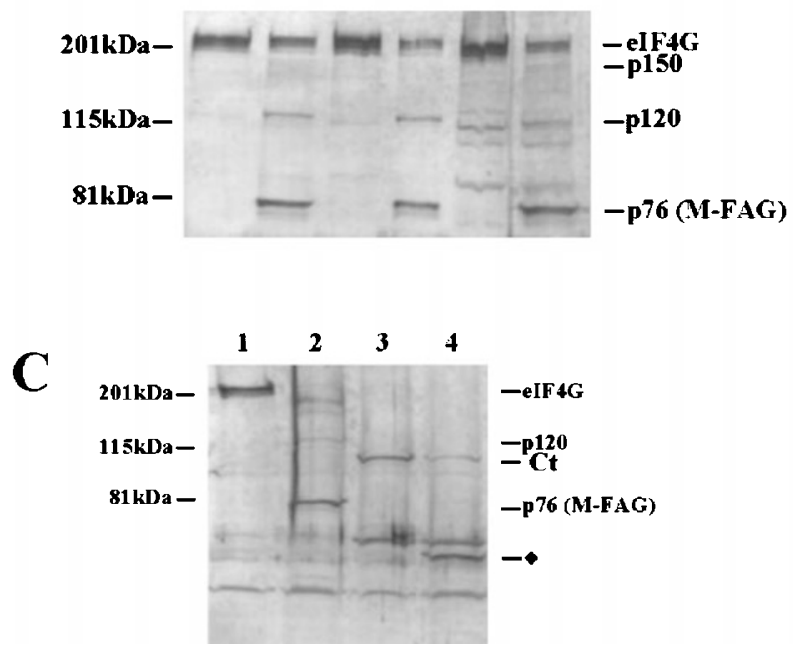

Figure 2 The p150, p120 and M-FAG cleavage fragments of elF4GI are associated with ribosomes and are distinct from those generated by $L$ protease. (A) Cells were incubated in the absence (lanes 1, 3,5) or presence (lanes 2, 4, 6) of $100 \mu \mathrm{g} / \mathrm{ml}$ cycloheximide for $4 \mathrm{~h}$ and cytoplasmic extracts prepared. Equal quantities of protein were either analysed directly (lanes 1 and 2), or used to prepare post-ribosomal supernatant (lanes 3 and 4) or ribosomes (lanes 5 and 6 ), as described in the Materials and Methods. Proteins were analyzed by SDS gel electrophoresis and immunoblotting with antiserum specific for elF4GI (antiserum W). (B) Equal amounts of cell extracts (lanes 1 and 2), post-ribosomal supernatants (lanes 3 and 4) or ribosomes (lanes 5 and 6 ) were subjected to affinity chromatography on $\mathrm{m}^{7}$ GTP-Sepharose to purify elF4E and associated proteins. Recovered protein was resolved by SDS gel electrophoresis and immunoblotted for elF4GI using antiserum W. (C) Reticulocyte lysate was incubated in the absence (lane 1) or presence of caspase-3 $(10 \mu \mathrm{g} / \mathrm{ml})$ (lane 2) or L protease $(0.3 \mu \mathrm{g} / \mathrm{ml}$ ) (lanes 3 and 4$)$ for $30 \mathrm{~min}$ at $30^{\circ} \mathrm{C}$, prior to the addition of buffer (lanes 1-3) or caspase-3 (lane 4) for a further $30 \mathrm{~min}$. Aliquots of lysate were analyzed by SDS gel electrophoresis and immunoblotting with antiserum specific for elF4GI (antiserum W). In each panel molecular mass markers and the positions of the major cleavage fragments of elF4GI are indicated. The diamond in (C) identifies a novel $L$ protease- and caspase-3-generated fragment of elF4GI. These data are from a single experiment but are representative of those obtained on three separate occasions

Note that the low molecular mass bands in lanes 1-4 which are recognised by antiserum $\mathrm{RL}$ are cross-reacting proteins which are distinct from the $\mathrm{N}-\mathrm{FAG}$ fragments. (C) Aliquots of cell extracts containing equal amounts of total cytoplasmic protein, prepared as above, were subjected to affinity chromatography on $\mathrm{m}^{7}$ GTP-Sepharose to purify elF4E and associated proteins. Recovered protein was resolved by SDS gel electrophoresis and immunoblotted for elF4GI and its cleavage fragments (using antisera $\mathrm{RL}$ and $\mathrm{E}$ ), elF4A, elF4E and the phosphorylated form of elF4E, as indicated. These data are from a single experiment but are representative of those obtained on five separate occasions 
E). In agreement with our previous findings, ${ }^{37}$ cleavage of elF4GI by caspase-3 in vitro generated fragments with the same mobility on SDS-gel electrophoresis as those observed in apoptotic (anti-Fas-stimulated) cells (Figure 3B, compare lanes 2 and 4). The immunoblots in Figure 3B (lanes 5-14) show that all the antisera recognised intact elF4GI in control and caspase-3-treated preparations of
FLAG-eIF4GI. The M-FAG doublet that appeared after incubation with caspase-3 was decorated only by antisera $W$ (lane 6) and $H$ (lane 8). Neither component of the doublet reacted with antiserum $E$ (lane 10), antiserum $R L$ (lane 12) or antiserum B (lane 14). The p150 fragment was recognised by antisera $\mathrm{W}$ (Figures 2 and 3B, lane 6), $\mathrm{H}$ (Figure 3B, lane 8), RL (Figure 3B, lane 12) and weakly by

A
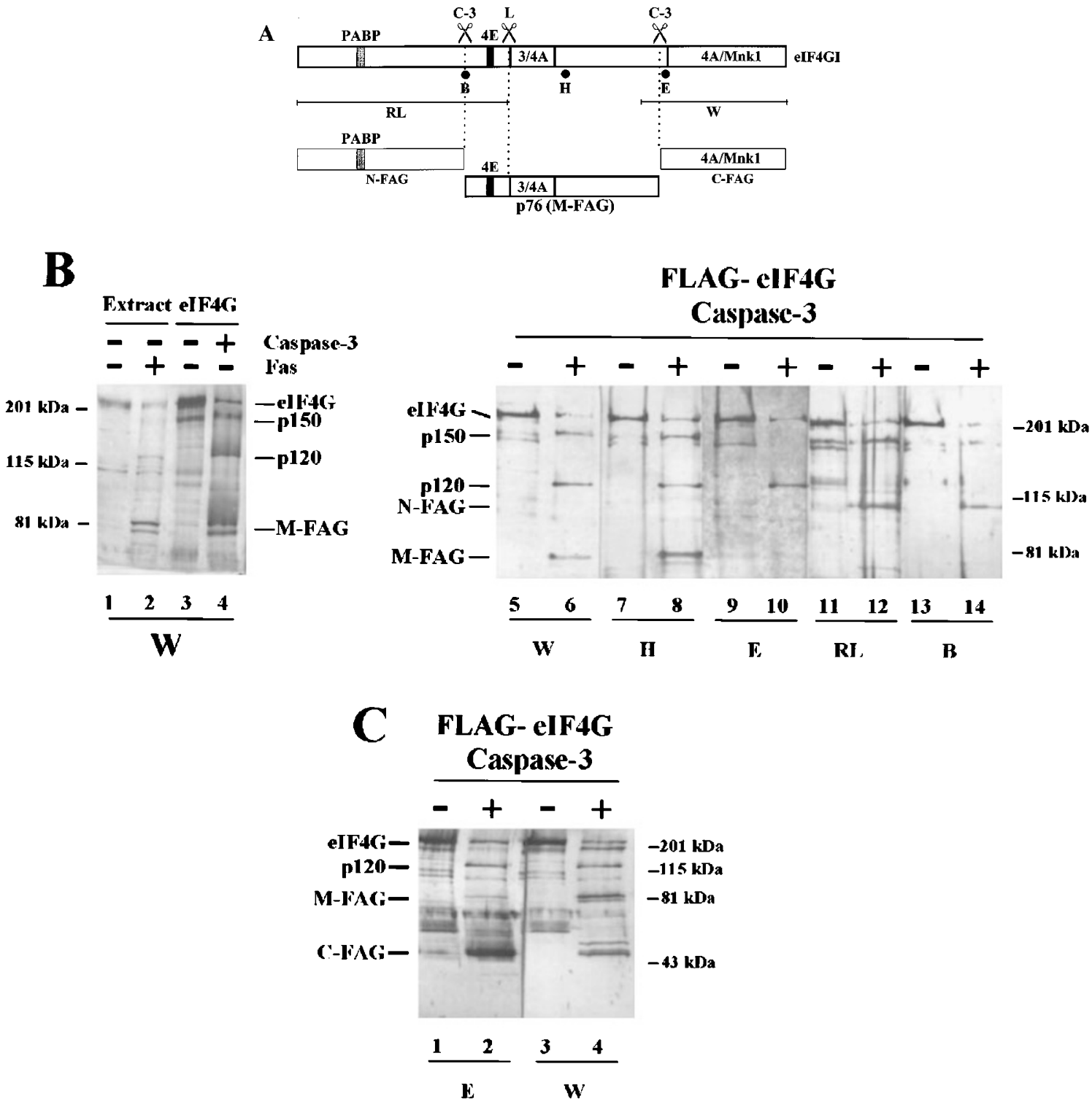

Figure 3 Localization of the caspase-3 cleavage sites of elF4GI by immunoblotting. (A) A diagrammatic representation of the major structural domains of elF4GI is shown, indicating the sites of interaction with PABP, elF4E, elF3 and elF4A, the $L$ protease cleavage site and regions of sequence used to generate specific antisera (see Materials and Methods). In addition, the two major caspase-3 cleavage sites, which lead to the generation of N-FAG, M-FAG and C-FAG are indicated (see text for details). (B) BJAB cells were incubated in the absence (lane 1) or presence (lane 2) of anti-Fas antiserum (500 $\mathrm{ng} / \mathrm{ml}$ ) for $4 \mathrm{~h}$. Extracts were prepared and resolved by electrophoresis on 7.5\% SDS gels. The gels were then immunoblotted with antiserum specific for elF4GI (antiserum W). Purified FLAG-elF4GI was incubated in the absence (lanes 3, 5, 7, 9,11 and 13) or presence (lanes 4, 6, 8,10,12 and 14) of recombinant caspase-3 as described in the Materials and Methods. elF4GI and its cleavage fragments were resolved by gel electrophoresis on $7.5 \%$ gels and identified by immunoblotting using the following domainspecific and sequence-specific antisera: lanes 3-6; W; lanes 7 and 8; H; lanes 9 and 10; E; lanes 11 and 12; RL; lanes 13 and 14; B. (C) Purified FLAG-elF4GI was incubated in the absence (lanes 1 and 3 ) or presence (lanes 2 and 4 ) of recombinant caspase-3 as described in (B). elF4GI and its cleavage fragments were then resolved by electrophoresis on 12.5\% SDS gels and visualised by immunoblotting using antiserum E (lanes 1 and 2) or W (lanes 3 and 4). Molecular mass markers and the positions of the major cleavage fragments of elF4GI are indicated. Note that the low molecular mass band stained with antiserum $E$ in lane 1 of (C) is a cross-reacting species which is distinct from C-FAG. These data are from a single experiment but are representative of those obtained on four separate occasions 
antiserum B (Figure 3B, lane 14). In addition, the antisera $\mathrm{RL}$ (Figure 3B, lane 12) and $\mathrm{B}$ (Figure 3B, lane 14) recognised a group of bands (N-FAG; see Figure 1) which correspond to the $\mathrm{N}$-terminal fragment of elF4GI (elF4GcpN). ${ }^{36}$ These results, and those presented in Figures 1 and 2, are consistent with the conclusion that the M-FAG fragment arises from cleavage of elF4GI at two sites and retains the elF4E and elF3 binding sites (Figure $3 A)$. The p120 and p150 fragments represent products from a single caspase- 3 cleavage event in the $\mathrm{N}$-terminal and $\mathrm{C}$ terminal halves of elF4GI, respectively, and are thus alternative intermediates in the generation of M-FAG (see Figure 1).

To determine precisely the cleavage sites in elF4GI we have subjected the M-FAG cleavage fragment to $\mathrm{N}$-terminal microsequencing. Purified FLAG-eIF4GI was cleaved in vitro with caspase-3, subjected to SDS gel electrophoresis and blotted on to PVDF membrane prior to protein sequencing of the M-FAG fragment. The sequence obtained, AFKEANPA(D)VPE (where the brackets indicate ambiguity in the residues identified), corresponds to a region in the deduced amino acid sequence of human elF4GI, comprising amino acids 493-503 (based on the numbering system employed by Imataka et al.; ${ }^{7}$ accession number AF104913). This indicates that caspase-3 cleavage had occurred on the C-terminal side of the sequence DLLD, between residues 492 and 493 . To identify the cleavage site at the C-terminus of elF4GI, fragments were resolved on a higher percentage acrylamide gel and C-FAG was identified with antisera $E$ (Figure $3 C$, lane 2) and W (Figure 3C, lane 4). Additionally, C-FAG derived from caspase-3 cleavage of native elF4GI in elF4F preparations was gel purified. Subsequent protein microsequencing, together with analysis by mass spectrometry (data not shown), gave the sequence $R(M) A R(G) T P A T K R S$. This establishes the second major caspase-3 cleavage site as being on the C-terminal side of the sequence DRLD, between residues 1136 and 1137. The calculated $M_{r}$ of the sequence that lies between amino acids 493 and 1136 of elFGI is 72244 . This agrees well with the estimated $M_{r}$ of $76 \mathrm{kDa}$ for M-FAG, which was obtained by comparison with the migration of molecular mass markers on SDS gel electrophoresis.

\section{Discussion}

The work described here sheds further light on the nature of the changes undergone by initiation factor elF4GI during apoptosis. ${ }^{42}$ We have previously shown that cells maintain a residual rate of protein synthesis for up to 2 days following induction of apoptosis in response to serum deprivation, treatment with anti-Fas antibody or exposure to etoposide. $^{34,35}$ The data indicate that, although full-length elF4GI is rapidly lost from apoptosing cells, three relatively longlasting cleavage fragments are generated, one of which (M$\mathrm{FAG}$ ) retains the ability to interact with other key initiation factors. Our results suggest that M-FAG may continue to permit some cap-dependent translation (albeit perhaps inefficiently) since it still interacts with elF4E, elF4A and ribosomes. Both the structure and the functional properties of the cleavage fragments of elF4GI that appear during apoptosis are distinct from those of the fragments produced in cells during picornavirus infection. ${ }^{28-32}$

Using a panel of elF4GI-specific antibodies (Figure 3), together with direct $\mathrm{N}$-terminal protein sequencing and mass spectrometry analysis (data not shown), we have established that the M-FAG fragment is generated from caspase-mediated cleavages between amino acids 492 and 493 at the N-terminus and amino acids 1136 and 1137 at the C-terminus. The sites of proteolysis lie immediately downstream of the sequences DLLD and DRLD respectively and are consistent with the known site preferences of caspase-3 for DXXD motifs. ${ }^{43}$ It is possible that some cleavage also occurs after the sequence DRGD (residues $1120 / 1121$ or $1133 / 1134$ ), giving rise to the doublet pattern of M-FAG observed on blots (Figures 1-3). However there are other DXXD sequences in elFGI which do not appear to be targeted by caspase-3, perhaps because they are inaccessible to the enzyme.

The ability of M-FAG to bind to elF4E and ribosomes is consistent with the identified cleavage sites since the domains that interact with elF4E, elF4A and elF3 remain in this fragment (Figure 3). Although one elF4A binding site in the C-terminal part of elF4G is absent from M-FAG (Figure 3 ), elF4A is still present in the $\mathrm{m}^{7}$ GTP-Sepharosepurified fraction from apoptotic cells (Figure 1C), probably because it can also bind to the central region of elF4GI. ${ }^{44}$ In contrast, M-FAG is predicted not to bind to PABP since the latter interacts with the N-terminus of elF4GI. ${ }^{6,7} \mathrm{We}$ have shown previously that the PABP which is present in an $\mathrm{m}^{7}$ GTP-Sepharose-purified fraction from control Jurkat cells is in fact selectively lost from this fraction after induction of apoptosis. ${ }^{34}$ Nevertheless, in the present study, a small amount of PABP remained associated with elF4E in apoptotic BJAB cells at a time when elF4G was cleaved completely, suggesting that PABP may also interact with another elF4E-associated factor.

Taken together these data suggest that a new form of elF4F, containing elF4E and elF4A but with M-FAG in place of full-length elF4GI, is associated with the ribosomes in apoptotic cells (Figure 4). This novel complex appears at about the time that the rate of translation is decreased. ${ }^{34,35}$ Unlike the situation in picornavirus-infected cells, where viral protease-mediated cleavage of elF4G separates the domain that interacts with elF4E from other functional regions of the protein, ${ }^{11,27,28,41}$ the modified form of elF4F that arises in apoptotic cells may still be able to support at least some cap-dependent initiation. Imataka and Sonenberg ${ }^{44}$ have shown that both binding sites for elF4A may be required for stimulating translation and it is possible therefore that the M-FAG-containing elF4F may be less efficient in mRNA unwinding activity. Nevertheless, two reports ${ }^{45,46}$ have recently shown that a central core domain of elF4G can still act in the recruitment of ribosomes to mRNA, in the absence of the C-terminal elF4A binding site.

The M-FAG-containing form of elF4F is also likely to be deficient in PABP-dependent re-initiation activity since the ability to cause circularisation of mRNA as a result of simultaneous interaction of PABP with poly $(A)$ (at the $3^{\prime}$ end) and of elF4E with the cap structure (at the $5^{\prime}$ 
A

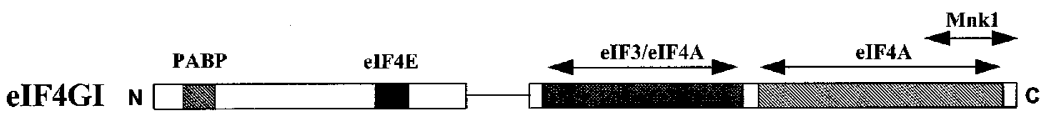

M-FAG N $\mathrm{N} \square-\square \mathrm{C}$

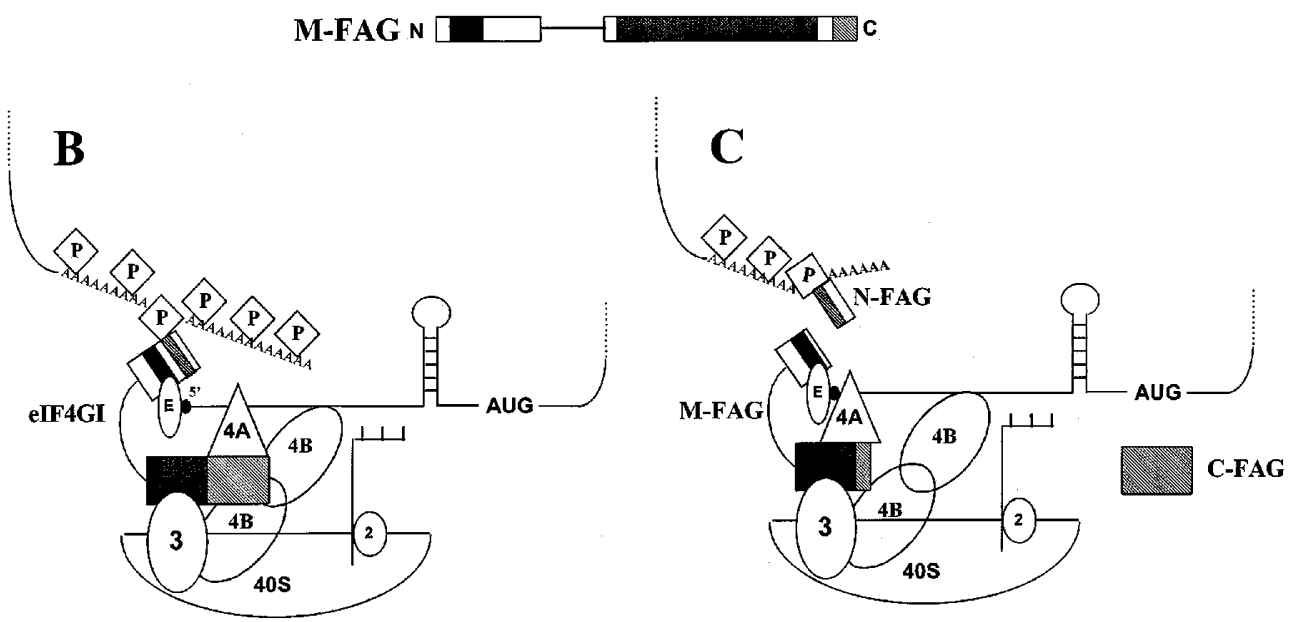

Figure 4 Model for the function of elF4GI in initiation before and after caspase-mediated cleavage in apoptotic cells. (A) Domain structures of intact elF4GI and the cleavage fragment M-FAG. Shaded regions indicate the sites of interaction with PABP, elF3, elF4A and the elF4E kinase Mnk1. The filled region indicates the site of interaction with elF4E. Note that binding sites for elF4E, elF3 and elF4A are retained in M-FAG but that the sites of interaction with PABP and Mnk1 are lost. (B) Components of the (40S ribosome.mRNA) initiation complex in non-apoptotic cells. The complex interacts with both the $5^{\prime}$ cap and $3^{\prime}$ poly $(A)$ tail of the mRNA molecule through elF4E (labelled E) and PABP (labelled P) respectively. (C) Proposed structure of the (40S ribosome.mRNA) initiation complex in apoptotic cells. The complex, which contains M-FAG in place of intact elF4GI, continues to interact with the mRNA cap structure via elF4E but is impaired in its ability to bind PABP and hence the poly(A) tail. The poly(A) tract may remain associated with PABP and the N-FAG fragment of elF4GI

end) ${ }^{7,12,14}$ will be reduced (see Figure 4). Furthermore, we have observed that the phosphorylation state of elF4E also decreases in BJAB cells following the induction of apoptosis (Figure 1). This may be an additional consequence of elF4G cleavage in that the ability of the elF4E kinase, Mnk1, to phosphorylate its substrate is likely to be compromised as a result of the loss of the proximity of Mnk1 to elF4E mediated by elF4G bridging. ${ }^{15}$ As discussed elsewhere, ${ }^{42}$ these several changes in the properties of elF4G could constitute the basis for the decrease in the rate of overall protein synthesis observed in apoptotic cells. ${ }^{34-36}$

Another possibility is that one or more of the elF4G cleavage fragments that accumulate in apoptotic cells may have a dominant-negative effect with respect to the functions of the intact factor. Since PABP binds to the $\mathrm{N}$ terminus of elF4GI ${ }^{7}$ the N-FAG fragment may impair the process of poly $(A)$-dependent initiation, or its regulation, by sequestering PABP (Figure 4). C-FAG may similarly interfere with elF4E phosphorylation by binding Mnk1. A fragment of a gene that encodes a mammalian homologue of the C-terminal part of elF4GI, variously called p97, DAP5 or NAT1, ${ }^{47-49}$ has been reported to protect HeLa cells against interferon- $\gamma$-induced apoptosis. Whereas p97/DAP5/NAT1 is distinct from M-FAG in that the former lacks the elF4E binding site, both M-FAG and C-FAG have some sequence similarities to p97/DAP-5/NAT1 and one or both may exert similar functions. ${ }^{42}$ Further work is underway to determine the functions of N-FAG, M-FAG and C-FAG in the regulation of translation, to characterise the M-FAGcontaining elF4F complex and to address the possible role of this complex in mediating cap-dependent and/or -independent translation in apoptotic cells.

\section{Materials and Methods}

\section{Materials}

Tissue culture materials were purchased from Life Technologies; cycloheximide was obtained from Sigma-Aldrich; purified caspase-3 was purchased from Autogen Bioclear (UK); agonistic anti-Fas antibody (clone $\mathrm{CH}-11$ ) was provided by Upstate Biotechnology; antiserum specific to poly(ADP-ribose) polymerase (PARP) was from Boehringer Mannheim.

\section{Cell culture and induction of apoptosis}

The EBV-negative Burkitt's lymphoma cell line BJAB was cultured as described by Clemens et al. ${ }^{34}$ Apoptosis was induced in BJAB cells by exposure to cycloheximide $(100 \mu \mathrm{g} / \mathrm{ml})$, anti-Fas antibody $(500 \mathrm{ng} / \mathrm{ml})$ or etoposide $(100 \mu \mathrm{g} / \mathrm{ml})$ for the times indicated in the individual Figure legends. The extent of apoptosis was monitored by the proportion of cells with less than a G0/G1 content of DNA, as determined by FACS analysis, and by the cleavage of PARP. ${ }^{34}$

\section{Preparation and analysis of cell extracts}

Cytoplasmic extracts of cells were prepared as described previously. ${ }^{34}$ Initiation factor elF4E and associated proteins were isolated by affinity chromatography on $\mathrm{m}^{7}$ GTP-Sepharose. ${ }^{17,35,50,51}$ Samples were subjected to electrophoresis on SDS polyacrylamide gels and the proteins transferred to PVDF membranes (Millipore) using a semi-dry blotting apparatus (Hoefer). Equal amounts of total protein or fractions purified on $\mathrm{m}^{7}$ GTP-Sepharose from equal amounts of cell 
extract were loaded on the gels. Ribosomal and post-ribosomal fractions of extracts from control and apoptotic cells were prepared as described previously. ${ }^{40}$

\section{Antisera}

Antibodies to elF4E, elF4A and the C-terminal region of elF4GI ${ }^{33}$ (amino acids 1079-1560 using the numbering system of Imataka et al. ${ }^{7}$ (antiserum W)) were as described previously. ${ }^{34,35,41}$ Additional antisera specific for elF4GI were developed in rabbits using the following peptides: KKEAVGDLLDAFKEVN (amino acids 483-498) (antiserum B); KKQKEMDEAATAEERERLKEELEEAR (amino acids 824-849) (antiserum H); RTPATKRTFSKEVEERSRERPSQPEGLR (amino acids 1139-1166) (antiserum E). Antiserum specific to the $\mathrm{N}$ terminus of elF4GI (antiserum RL) was described previously. ${ }^{36,52}$ Immunoblots were developed and quantified as in earlier studies. ${ }^{34,35}$

\section{Preparation of recombinant proteins}

$1 \times 10^{6}$ plaques from a HeLa cell cDNA expression library (Stratagene) were screened by hybridization with a Bg/l DNA fragment (labelled by random priming) spanning the first 700 nucleotides of plasmid $p 4 / 16 .{ }^{6}$ Positive clones were recovered and were further analyzed by PCR with primers specific for the elF4GI gene and the bacteriophage T3 promoter. PCR fragments were purified on Quiaquick (QIAGEN) columns and sequenced. Two clones (8/1 and 2/1) containing the longest $5^{\prime}$ end inserts were isolated by three successive rounds of plating and screening by PCR. Plasmids were then rescued from lambda phage infected cells by in vivo excision using the ExAssist/ SOLR system (Stratagene). Analysis of the $3^{\prime}$ end sequences showed that they encoded elF4GI (up to nucleotides 1135 for 2/1 and 1556 for $8 / 1$ ). Although the $5^{\prime}$ sequences overlapped with the $p 4 / 16$ insert, ${ }^{6}$ the 8/1 (accession number AF002815) and 2/1 (accession number AF002816) clones were distinct at their $5^{\prime}$ ends. The reading frames deduced from these sequences were in frame with the published elF4GI amino acid sequence and with the p4/16 open reading frame, but they were each different at their $\mathrm{N}$ termini and lacked an identifiable $5^{\prime}$ non-coding sequence. The DNA sequence was confirmed twice for each clone by sequencing both strands.

To express elF4GI in baculovirus the multiple cloning site of the baculovirus transfer vector pBackPac (Clontech) was modified by insertion of two annealed oligonucleotides: (gatccACCATGGACTACAAGGACGACGATGACAAGCCCGGGATACGAATTCGAC and tcgaGTCGAATTCGTATCCCGGGCTTGTCATCGTCGTCCTTGTAGTCCATGGTg) between the BamHI and $X$ hol sites. The resulting plasmid (pBac-pak His2) contained the FLAG epitope sequence followed by Xmal and EcoRI sites. The $5^{\prime}$ terminal Xmal-EcoRI fragment of $\mathrm{p} 8 / 1$, followed by the EcoRI insert of plasmid pHFC $1,{ }^{5}$ were successively subcloned in pBac-pak His2. The entire elF4GI sequence fused to the FLAG epitope was purified after complete digestion with $\mathrm{Xhol}$ and partial digestion with BamHI and then subcloned into a second baculovirus shuttle vector, pFASTbac (Life Technologies). The pFASTbac-FLAG-eIF4GI was then introduced into the $E$. coli strain (DH10bac) containing the Bacmid and recombinant baculovirus was obtained following the manufacturer's instructions (Life Technologies). FLAG-elF4GI was purified from Sfg insect cells infected for $72 \mathrm{~h}$ with the recombinant baculovirus. Cells were harvested and resuspended in $5 \mathrm{ml}$ per $100 \mathrm{ml}$ culture of lysis buffer (50 mM MOPS, pH 7.2, $100 \mathrm{mM} \mathrm{NaCl}, 5 \mathrm{mM}$ EDTA, $5 \mathrm{mM}$ EGTA, $1 \mathrm{mM}$ phenylmethylsulphonyl fluoride and $1 \mathrm{mM}$ benzamidine), lysed by addition of IGEPAL (Sigma) to $1 \%$ (by volume) and clarified by centrifugation at $15000 \times g$ for $20 \mathrm{~min}$ at $4^{\circ} \mathrm{C}$. The supernatant was applied to anti-FLAG-M2 affinity gel (Anachem, UK), washed in Buffer
A (20 mM MOPS, pH 7.2, $50 \mathrm{mM} \mathrm{NaCl,} 5$ mM EDTA, 5 mM EGTA, $1 \mathrm{mM}$ phenylmethylsulphonyl fluoride and $1 \mathrm{mM}$ benzamidine) and stored at $-80^{\circ} \mathrm{C}$ in aliquots. Recombinant Foot-and-Mouth-Disease Virus $L$ protease was prepared as described previously. ${ }^{28,40,41}$

\section{Determination of cleavage sites in elF4GI}

FLAG-elF4GI (in Buffer A) was incubated with recombinant caspase-3 $(10 \mu \mathrm{g} / \mathrm{ml})$ for $30 \mathrm{~min}$ at $37^{\circ} \mathrm{C}$, as described in the Figure legends. Samples were resolved by SDS-PAGE and proteins transferred to PVDF. Following identification of the cleavage fragments in adjacent tracks by immunoblotting, bands were excised and subjected to mass spectrometry and $\mathrm{N}$-terminal sequencing using in-house facilities at the University of Sussex and the University of Oklahoma Health Sciences Center.

\section{Acknowledgements}

We thank Dr Anne Gatignol (ICGM, Paris) for the gift of the Hela cell cDNA library, $P$ Vende (Jouy-en-Josas, France) for the cloning and sequencing of elF4GI constructs, DrR Rhoads (Shreveport, Louisiana, USA) for the gift of pHFC1, A Gillman-Smith for help with mass spectrometry and N Castagné for skilful technical assistance. We also thank Dr Jenny Pain, Dr Linda McKendrick, Dr Ruth Simon, Ms Wendy Wood and Ms Gill Carpenter for helpful discussions. This research was supported by grants from The Royal Society, The Leukaemia Research Fund, The Cancer Prevention Research Trust and The Wellcome Trust (grant numbers 045619 and 056778). During the performance of this work M Bushell was funded by a BBSRC Industrial CASE Studentship in SJ Morley's laboratory, in collaboration with Roche Discovery (Welwyn Garden City). SJ Morley is a Senior Research Fellow of the Wellcome Trust.

\section{References}

1. Merrick WC and Hershey JWB (1996) The pathway and mechanism of protein synthesis. In: Translational control, Hershey JWB, Mathews MB and Sonenberg $\mathrm{N}$, eds (Cold Spring Harbor, New York: Cold Spring Harbor Laboratory Press) pp. $31-70$

2. Morley SJ, Curtis PS and Pain VM (1997) elF4G: Translation's mystery factor begins to yield its secrets. RNA Publ. RNA Soc. 3: 1085-1104

3. Hentze M (1997) elF4G: A multipurpose ribosome adaptor? Science 275: 500 501

4. Gradi A, Imataka $\mathrm{H}$, Svitkin $\mathrm{YV}$, Rom E, Raught $\mathrm{B}$, Morino $\mathrm{S}$ and Sonenberg $\mathrm{N}$ (1998) A novel functional human eukaryotic translation initiation factor 4G. Mol. Cell. Biol. 18: 334-342

5. Yan R, RychlikW, Etchison D and Rhoads RE (1992) Amino acid sequence of the human protein synthesis initiation factor elF-4gamma. J. Biol. Chem. 267: 23226-23231

6. Piron M, Vende $P$, Cohen J and Poncet $D$ (1998) Rotavirus RNA-binding protein NSP3 interacts with elF4Gl and evicts the poly(A) binding protein from elF4F. EMBO J. 17: 5811-5821

7. Imataka H, Gradi A and Sonenberg N (1998) A newly identified N-terminal amino acid sequence of human elF4G binds poly(A)-binding protein and functions in poly(A)-dependent translation. EMBO J. 17: 7480-7489

8. Johannes $G$ and Sarnow $P$ (1998) Cap-independent polysomal association of natural mRNAs encoding c-myc, BiP, and elF4G conferred by internal ribosome entry sites. RNA Publ. RNA Soc. 4: 1500-1513

9. Merrick WC (1994) Eukaryotic protein synethesis: An in vitro analysis. Biochimie 76: $822-830$

10. MaderS, Lee H, Pause A and SonenbergN (1995) The translation initiation factor elF-4E binds to a common motif shared by the translation factor elF-4gamma and the translational repressors 4E-binding proteins. Mol. Cell. Biol. 15: 4990-4997

11. Lamphear BJ, Kirchweger R, Skern T and Rhoads RE (1995) Mapping of functional domains in eukaryotic protein synthesis initiation factor $4 G$ (elF4G) with picornaviral proteases - implications for cap-dependent and capindependent translational initiation. J. Biol. Chem. 270: 21975-21983 
12. Tarun Jr SZ and Sachs AB (1996) Association of the yeast poly(A) tail binding protein with translation initiation factor elF-4G. EMBO J. 15: 7168-7177

13. Le H, Tanguay RL, Balasta ML, Wei CC, Browning KS, Metz AM, Goss DJ and Gallie DR (1997) Translation initiation factors elF-iso4G and elF-4B interact with the poly $(A)$-binding protein and increase its RNA binding activity. J. Biol. Chem. 272: $16247-16255$

14. Tarun Jr SZ, Wells SE, Deardorff JA and Sachs AB (1997) Translation initiation factor elF4G mediates in vitro poly(A) tail-dependent translation. Proc. Natl. Acad. Sci. USA 94: 9046-9051

15. Pyronnet $\mathrm{S}$, Imataka $\mathrm{H}$, Gingras AC, Fukunaga R, Hunter T and Sonenberg $N$ (1999) Human eukaryotic translation initiation factor 4G (elF4G) recruits Mnk1 to phosphorylate elF4E. EMBO J. 18: 270-279

16. Haghighat A and Sonenberg N (1997) elF4G dramatically enhances the binding of elF4E to the mRNA 5'-cap structure. J. Biol. Chem. 272: 21677-21680

17. Morley SJ and McKendrick L (1997) Involvement of stress-activated protein kinase and p38/RK mitogen-activated protein kinase signaling pathways in the enhanced phosphorylation of initiation factor 4E in NIH $3 \mathrm{~T} 9$ cells. J. Biol. Chem. 272: $17887-17893$

18. Flynn A and Proud CG (1996) Insulin-stimulated phosphorylation of initiation factor 4E is mediated by the MAP kinase pathway. FEBS Lett. 389: 162-166

19. Mendez R, Myers Jr MG, White MF and Rhoads RE (1996) Stimulation of protein synthesis, eukaryotic translation initiation factor 4Ephosphorylation, and PHASI phosphorylation by insulin requires insulin receptor substrate 1 and phosphatidylinositol 3-kinase. Mol. Cell. Biol. 16: 2857-2864

20. Sonenberg N (1996) mRNA 5' cap-binding protein elF4E and control of cell growth. In Translational Control, Hershey JWB, Mathews MB and Sonenberg N, eds (Cold Spring Harbor: Cold Spring Harbor Laboratory Press) pp. 245-269

21. Lazaris-Karatzas A, Montine KS and Sonenberg N (1990) Malignant transformation by a eukaryotic initiation factor subunit that binds to mRNA 5 cap. Nature 345: 544-547

22. Fukuchi-Shimogori $\mathrm{T}$, Ishii I, Kashiwagi K, Mashiba H, Ekimoto H and Igarashi $\mathrm{K}$ (1997) Malignant transformation by overproduction of translation initiation factor elF4G. Cancer Res. 57: 5041-5044

23. Brass N, Heckel D, Sahin U, Pfreundschuh M, Sybrecht GW and Meese E (1997) Translation initiation factor elF-4gamma is encoded by an amplified gene and induces an immune response in squamous cell lung carcinoma. Hum. Mol. Genet. 6: 33-39

24. Nathan CAO, Liu L, Li BD, Abreo FW, Nandy I and De Benedetti A (1997) Detection of the proto-oncogene elF4E in surgical margins may predic recurrence in head and neck cancer. Oncogene 15: 579-584

25. Nathan CA, CarterP, Liu L, LiBD, Abreo F, Tudor A, Zimmer SG and De Benedetti A (1997) Elevated expression of elT4E and FGF-2 isoforms during vascularization of breast carcinomas. Oncogene 15: 1087-1094

26. Svitkin YV, Gradi A, Imataka H, Morino S and Sonenberg N (1999) Eukaryotic initiation factor 4GII (elF4GII), but not elF4GI, cleavage correlates with initiation of host cell protein synthesis after human rhinovirus infection. J. Virol. 73:34673472

27. Lamphear BJ, Yan R, Yang F, Waters D, Liebig H-D, Klump H, Kuechler E, Skern T and Rhoads RE (1993) Mapping the cleavage site in protein synthesis initiation factor elF-4gamma of the $2 \mathrm{~A}$ proteases from human Coxsackievirus and rhinovirus. J. Biol. Chem. 268: 19200-19203

28. Ohlmann T, Rau M, Pain VM and Morley SJ (1996) The C-terminal domain of eukaryotic protein synthesis initiation factor (elF) $4 \mathrm{G}$ is sufficient to support capindependent translation in the absence of elF4E. EMBO J. 15: 1371-1382

29. Ziegler E, Borman AM, Kirchweger R, Skern T and Kean KM (1995) Foot-andmouth disease virus $L b$ proteinase can stimulate rhinovirus and enterovirus IRES-driven translation and cleave several proteins of cellular and viral origin. J. Virol. 69: 3465-3474

30. Ziegler E, Borman AM, Deliat FG, Liebig HD, Jugovic D, Kean KM, Skern T and Kuechler E (1995) Picornavirus 2A proteinase-mediated stimulation of internal initiation of translation is dependent on enzymatic activity and the cleavage products of cellular proteins. Virology 213: $549-557$

31. Borman AM, Kirchweger R, Ziegler E, Rhoads RE, Skern T and Kean KM (1997) elF4G and its proteolytic cleavage products: Effect on initiation of protein synthesis from capped, uncapped, and IRES-containing mRNAs. RNA 3: 186-196

32. De Gregorio E, Preiss T and Hentze MW (1998) Translational activation of uncapped mRNAs by the central part of human elF4G is $5^{\prime}$ end-dependent. RNA Publ. RNA Soc. 4: 828-836
33. Pestova TV, Shatsky IN and Hellen CUT (1996) Functional dissection of eukaryotic initiation factor $4 \mathrm{~F}$ : The $4 \mathrm{~A}$ subunit and the central domain of the $4 \mathrm{G}$ subunit are sufficient to mediate internal entry of $43 \mathrm{~S}$ preinitiation complexes. Mol. Cell. Biol. 16: 6870-6878

34. Clemens MJ, Bushell M and Morley SJ (1998) Degradation of eukaryotic polypeptide chain initiation factor (elF) $4 \mathrm{G}$ in response to induction of apoptosis in human lymphoma cell lines. Oncogene 17: 2921-2931

35. Morley SJ, McKendrick L and Bushell M (1998) Cleavage of translation initiation factor $4 G$ (elF4G) during anti-Fas IgM-induced apoptosis does not require signalling through the p38 mitogen-activated protein (MAP) kinase. FEBS Lett. 438: $41-48$

36. Marissen WE and Lloyd RE (1998) Eukaryotic translation initiation factor $4 G$ is targeted for proteolytic cleavage by caspase 3 during inhibition of translation in apoptotic cells. Mol. Cell. Biol. 18: 7565-7574

37. Bushell M, McKendrick L, Janicke RU, Clemens MJ and Morley SJ (1999) Caspase- 3 is necessary and sufficient for cleavage of protein synthesis eukaryotic initiation factor $4 \mathrm{G}$ during apoptosis. FEBS Lett. 451: 332-336

38. Bushell M, Wood W, Clemens MJ and Morley SJ (2000) Changes in integrity and association of eukaryotic protein synthesis initiation factors during apoptosis. Eur. J. Biochem. 267: 1083-1091

39. Fraser CS, Pain VM and Morley SJ (1999) The association of initiation factor 4F with Poly $(A)$-binding protein is enhanced in serum-stimulated Xenopus kidney cells. J. Biol. Chem. 274: 196-204

40. Rau M, Ohlmann T, Morley SJ and Pain VM (1996) A reevaluation of the capbinding protein, elF4E, as a rate-limiting factor for initiation of translation in reticulocyte lysate. J. Biol. Chem. 271: 8983-8990

41. OhImann T, Pain VM, Wood W, Rau M and Morley SJ (1997) The proteolytic cleavage of eukaryotic initiation factor (eIF) $4 \mathrm{G}$ is prevented by elF4E binding protein (PHAS-I;4E-BP1) in the reticulocyte lysate. EMBO J. 16: 844-855

42. Clemens MJ, Bushell M, Jeffrey IW, Pain VM and Morley SJ (2000) Translation initiation factor modifications and the regulation of protein synthesis in apoptotic cells. Cell Death Differ. 7: 603-615

43. Talanian RV, Quinlan C, Trautz S, Hackett MC, Mankovich JA, Banach D, Ghayur T, Brady KD and Wong WW (1997) Substrate specificities of caspase family proteases. J. Biol. Chem. 272: 9677-9682

44. Imataka $\mathrm{H}$ and Sonenberg $\mathrm{N}$ (1997) Human eukaryotic translation initiation factor $4 G$ (eIF4G) possesses two separate and independent binding sites for elF4A. Mol. Cell. Biol. 17: 6940-6947

45. De Gregorio E, Preiss T and Hentze M (1999) Translation driven by an elF4G core domain in vivo. EMBO J. 18: 4865-4874

46. Morino S, Imataka H, Svitkin YV, Pestova TV and Sonenberg N (2000) Eukaryotic translation initiation factor $4 \mathrm{E}$ (elF4E) binding site and the middle onethird of elF4GI constitute the core domain for cap-dependent translation, and the C-terminal one-third functions as a modulatory region. Mol. Cell. Biol. 20: 468477

47. Imataka H, Olsen HS and Sonenberg N (1997) A new translational regulator with homology to eukaryotic translation initiation factor 4 G. EMBO J. 16: 817-825

48. Levy-Strumpf N, Deiss LP, Berissi H and Kimchi A (1997) DAP-5, a novel homolog of eukaryotic translation initiation factor $4 G$ isolated as a putative modulator of gamma interferon-induced programmed cell death. Mol. Cell. Biol. 17: $1615-1625$

49. Yamanaka S, Poksay KS, Arnold KS and Innerarity TL (1997) A novel translational repressor $m R N A$ is edited in livers containing tumors caused by the transgene expression of the ApoB-mRNA editing enzyme. Genes Dev. 11: 321-333

50. Morley SJ and Pain VM (1995) Hormone-induced meiotic maturation in Xenopus oocytes occurs independently of p70 $70^{\text {s6k }}$ activation and is associated with enhanced initiation factor (eIF)-4F phosphorylation and complex formation. J. Cell Sci. 108: $1751-1760$

51. Morley SJ and Pain VM (1995) Translational regulation during activation of porcine peripheral blood lymphocytes: Association and phosphorylation of the $\alpha$ and gamma subunits of the initiation factor complex elF-4F. Biochem. J. 312: $627-635$

52. Lloyd RE, Jense HG and Ehrenfeld E (1987) Restriction of translation of capped mRNA in vitro as a model for poliovirus-induced inhibition of host-cell protein synthesis - relationship to p200 cleavage. J. Virol. 61:2480-2488 